\title{
Occurrence of rare earth element and yttrium (REY) in Tanjung formation coking coal from Sekako area, Central Kalimantan
}

\author{
Hendra Amijaya*, Beny Wiranata, and Ferian Anggara
}

Department of Geological Engineering, Faculty of Engineering, Universitas Gadjah Mada, Jl. Grafika No. 2, Yogyakarta 55281, Indonesia

\begin{abstract}
Inorganic geochemistry of coal become a point of interest on coal study, especially relating with the occurrence of rare earth element. Tanjung Formation is one of coking coal bearing deposits in Barito Basin, Central Kalimantan. The aims of this study to determine the occurrence of Rare Earth Element and Yttrium (REY) especially in term of concentration and enrichment type in coal seam A and B of Tanjung Formation in Sekako Area, Central Kalimantan. A number of 10 coal samples were collected from both seams. Inductively Coupled Plasma-Atomic Spectroscopy (ICP-AES) analysis was conducted to determine the REY in coal. Based on this study, coal seam A and B generally have very low concentration of REY elements deposits. The REY elements of coal seam A and B in the study area are typically characterized with $\mathrm{M}$ and $\mathrm{H}$-type enrichment, which might be caused by the mafic basalt rocks in the surroundings. Keywords: REE, Yttrium coking coal, Tanjung Formation, Kalimantan
\end{abstract}

\section{Introduction}

Rare earth element (REE) is an element found in the earth's crust with very limited abundance. REE is a group of lanthanides consisting of 17 elements on the periodic table of elements. REE elements are usually also called REY if yttrium elements are included [1]. REY is a critical element that is needed for high-tech modern industries [2, 3]. In general, economical or conventional REY resources are found in igneous rocks, especially granitoid rocks that usually associated with monazite, bastnaesite, and xenotime minerals [4]. However, coals is also an economic source for critical element including trace element, REY and also some base metals [5].

The abundance of REY elements in coal in some areas is relatively similar to the conventional source of REY element concentration and indicated that coal as a potential source for REY [3]. On the other hand, nowadays the utilization of REY from coal and fly or bottom ash has been developed. Fly or bottom ash is a by-product of the coal combustion process as steam coal for electricity generation. Recent study on fly or bottom ash from Indonesia power plants, indicated that REY concentration in the coal ash is about 10 times higher than in the raw coal [6].

The mode of occurrence or enrichment of REY elements in coal can be caused by various processes including terrigenous, tuffaceous, infiltration and hydrothermal [2]. The enrichment type of REY deposits in coal divided into L-type $(\mathrm{LaN} / \mathrm{LuN}>1)$, M- type $(\mathrm{LaN} / \mathrm{SmN}<1$, and $\mathrm{GdN} / \mathrm{LuN}>1$ ), and H-type $(\mathrm{LaN} / \mathrm{LuN}<1)$ [7]. The anomalies of REY in coal including anomalies of redox-sensitive $\mathrm{Ce}$ and $\mathrm{Eu}$, and also non-redox-sensitive of $\mathrm{La}, \mathrm{Gd}$, and $\mathrm{Y}$ are geochemical indicators to interpreted the origin area of sediment, sedimentary environment, tectonic evolution, and the geological history after deposition [2]. These elements are formed and distributed in organic material or formed as inorganic material in coal.

Indonesia has total coal resources of around $125277.59 \times 10^{6} \mathrm{t}$ [8]. Barito basin is one of the Tertiary age sedimentary basins in Indonesia [9, 10]. Eocene coal in Barito and Kutai Basin are generally bituminous coal with low to medium ash content and relatively varied sulphur content, which some can be used as the material for metallurgical coke or known as coking coal. In general, coking coal in Kalimantan is found in the Tanjung Formation and Batu Ayau Formation [11]. The study on the characteristics of the Tanjung Formation coal both in terms of organic petrographic and geochemical characteristics has been widely carried out. The occurrence of REY elements deposits in Tanjung Formation coal have not been examined. This study aims to determine the concentration, possible enrichment type of REY elements deposits in coal seam A and B of Tanjung Formation in Sekako Area, Central Kalimantan.

\section{Geological settings}

Barito Basin is one of the major basins which is located in the Eastern part of Kalimantan Island. The basin was formed starting in the Late Cretaceous and then followed by the collision between Schwaner and Paternoster microcontinent. The extensional deformation process in Paleogene that initiated the rifting process as an accommodation space for sediment deposits [12].

The Eocene - Oligocene Tanjung Formation is the oldest formation and it was deposited in a synrift and postrift sequence in the Barito Basin. [13-15]. Lower Tanjung Formation is comprised by alternation of sandstone, shale, siltstone and polymic conglomerate, while the upper part of Tanjung Formation is comprised of alternation of micaceous quartz sandstone, siltstone,

\footnotetext{
* Corresponding author: hamijaya@gadjahmada.edu
} 
limestone and coal [14]. The coal in this formation is typically bituminous coal which is predominantly composed of vitrinite maceral and a lesser inertinite and liptinite. The coal also has low ash content $(<15 \%)$ and varied total sulfur content, and also with high calorific value $[9,10,16]$.

In the studied area, volcanic rock deposit is also found. This deposit is known as Kasale volcanic, which contains pyroxene basalt in form of dykes and plug. This volcanic rock is Late Cretaceous in age [14].

\section{Methods}
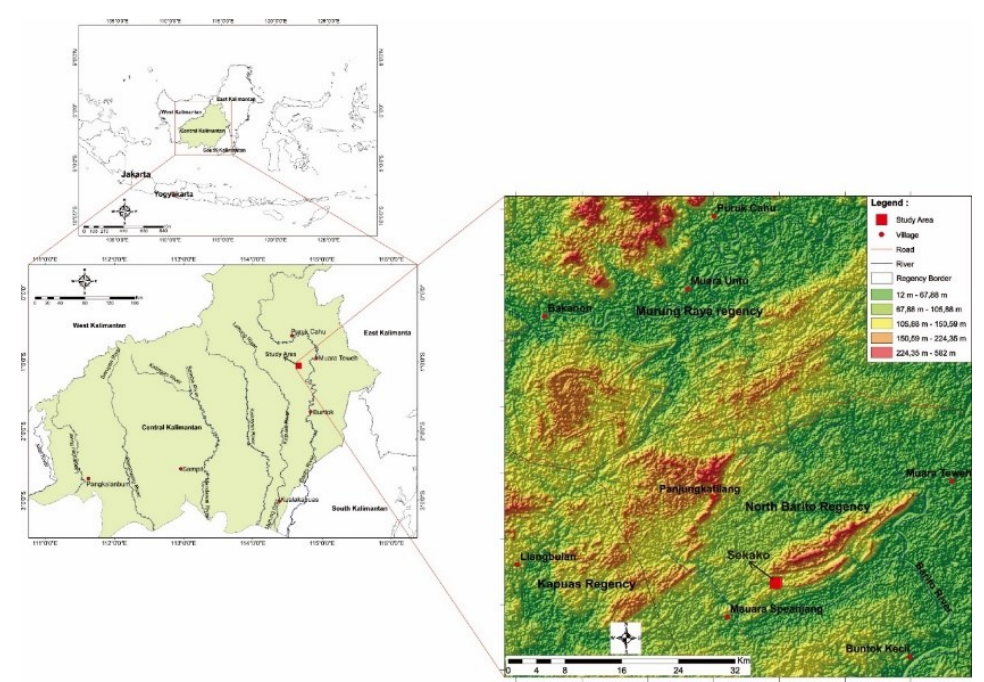

Fig. 1. The location of study area (modified map from [21], see [20]).

Coking coal samples were taken from the Tanjung Formation located in Sekako Area, Central Kalimantan (Figure 1). Coal seam A and B were observed. A total of 4 coal samples were taken from coal seam A and 6 coal samples were taken from coal seam B. The coal sampling conducted by channel sampling ply by ply method [17]. The macroscopic analysis of coal lithotype was following to Australian Standard with modification [18].

Inductively Coupled Plasma-Atomic Spectroscopy (ICP-AES) was conducted to determine the REY and trace element distribution in coal. The ICPAES was conducted at ALS Canada Ltd. in Vancouver, Canada. The REY deposits of the coal were normalized to the REY value of Upper Continental Crust (UCC) [19]. In this study the ratio of EuN/EuN*, YN/HoN, and LaN/LaN* were also calculated. The ratio of EuN/EuN* $=\mathrm{EuN} /(0.5 \mathrm{SmN}+0.5 \mathrm{GdN})$ and the ratio of $\mathrm{LaN} / \mathrm{LaN}^{*}$ $=\mathrm{LaN} /(3 \mathrm{PrN}-2 \mathrm{NdN})[1]$.

\section{Result and discussion}

Coal seam A and seam B have a thickness of approximately $1.5 \mathrm{~m}$ and $3 \mathrm{~m}$. Both of coal seams are dominated by bright and banded bright coal lithotype [20]. These coal seam also have some inorganic parting layers that consist of claystone (Figure 2). Coal seam A contains Lanthanum (La) of 0.08 (ppm), Cerium (Ce) of 0.08 (ppm), Praeseodymium (Pr) of $0.10 \mathrm{ppm}$, Neodymium $(\mathrm{Nd})$ of $0.12(\mathrm{ppm})$, Samarium $(\mathrm{Sm})$ of $0.16 \mathrm{ppm}$, Europium (Eu) of $0.23 \mathrm{ppm}$, Gadolinium (Gd) of $0.18 \mathrm{ppm}$, Terbium (Tb) of $0.15 \mathrm{ppm}$, Dysprosium (Dy) of $0.17 \mathrm{ppm}$, Yttrium (Y) of $0.16 \mathrm{ppm}$, Holmium (Ho) of 0.13 ppm, Erbium (Er) of 0.16 ppm, Thulium (Tm) of $0.14 \mathrm{ppm}$, Ytterbium $(\mathrm{Yb})$ of 0.18 ppm, and Lutetium (Lu) of 0.18 ppm (Figure 3a).

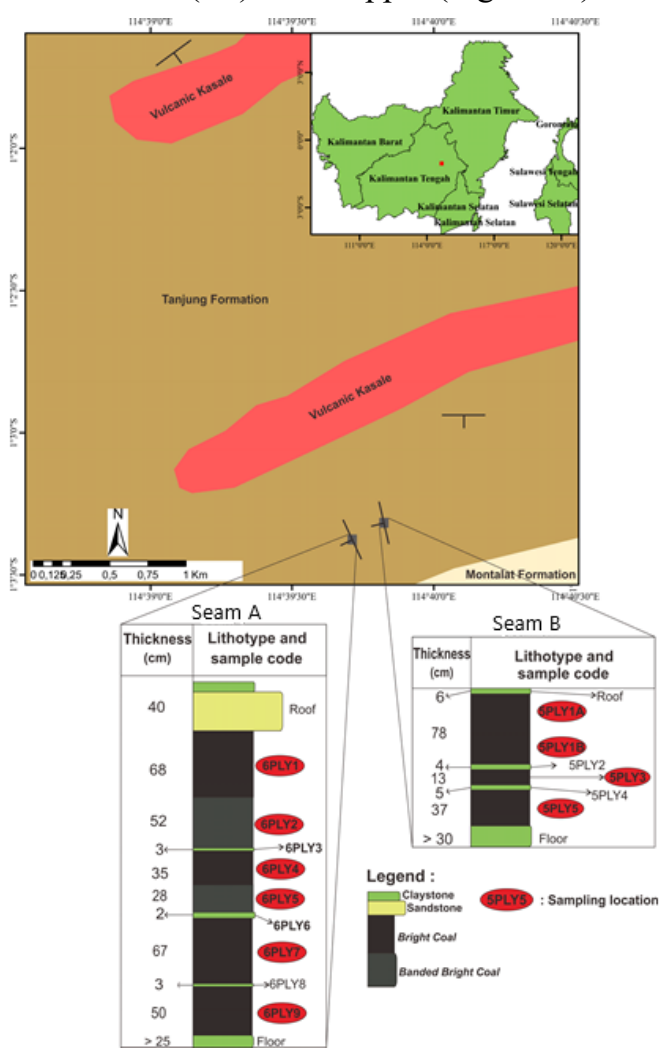

Fig. 2. The vertical section of coal seam A and B. Geological map of the area. [14].

Meanwhile, coal seam B contains Lanthanum (La) of $0.10(\mathrm{ppm})$, Cerium (Ce) of $0.10 \quad(\mathrm{ppm})$, Praeseodymium (Pr) of 0.10 ppm, Neodymium $(\mathrm{Nd})$ of 0.11 (ppm), Samarium (Sm) of 0.15 ppm, Europium (Eu) of $0.14 \mathrm{ppm}$, Gadolinium (Gd) of $0.14 \mathrm{ppm}$, Terbium (Tb) of $0.11 \mathrm{ppm}$, Dysprosium (Dy) of 0.13 ppm, Yttrium (Y) of 0.13 ppm, Holmium (Ho) of 0.12 ppm, Erbium (Er) of $0.12 \mathrm{ppm}$, Thulium (Tm) of 0.11 ppm, Ytterbium $(\mathrm{Yb})$ of $0.12 \mathrm{ppm}$, and Lutetium (Lu) of 0.10 ppm (Figure 3a).

In general, coal seam A and B in the study area predominantly composed of Medium Rare Earth Element (MREE), and followed by Heavy Rare Earth Element (LREE) and Light Rare Earth Element (LREE) (Figure 3b). 5PLY1A and 5PLY1B samples from coal seam A are typically characterized with M-type enrichment with the $\mathrm{LaN} / \mathrm{LuN}$ value of varies from 0.43 to $0.53, \mathrm{LaN} / \mathrm{SmN}$ varies from 0.35 to 0.42 , and GdN/LuN varies from 1.15 to 1.31 . While 5PLY3 and 5PLY5 coal samples are generally characterized by Htype enrichment with $\mathrm{LaN} / \mathrm{LuN}$ value of varies from 0.28 to $0.50, \mathrm{LaN} / \mathrm{SmN}$ varies from 0.32 to 0.68 , and $\mathrm{GdN} / \mathrm{LuN}$ varies from 0.91 to 0.95 . 


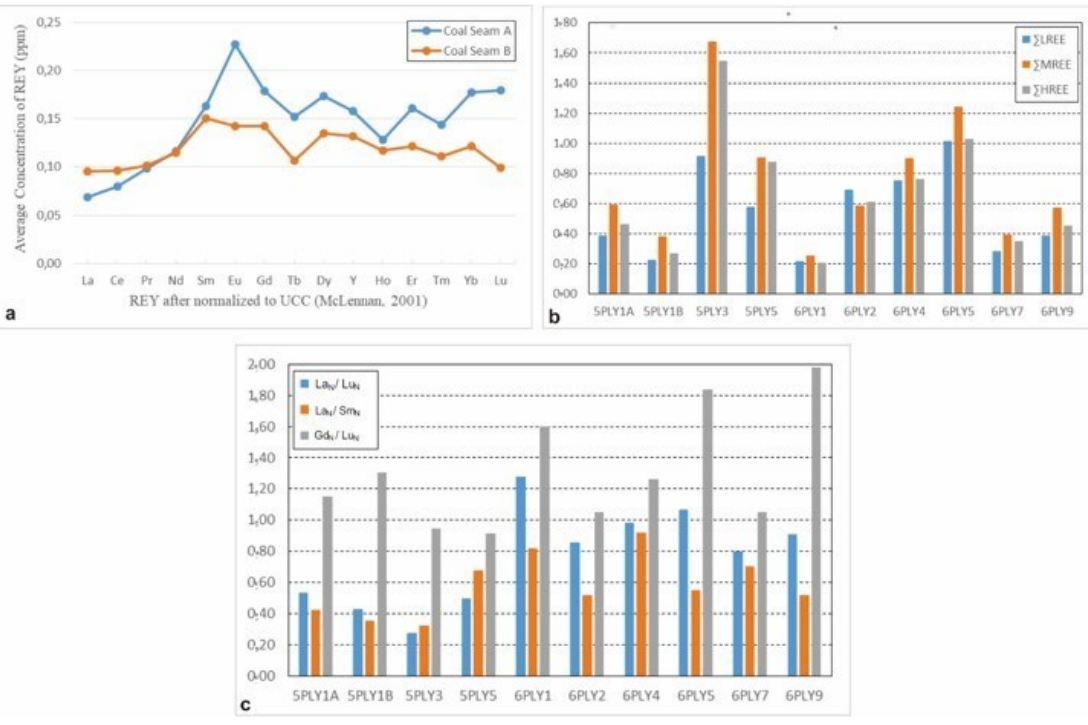

Fig. 3. a. Concentration of REY of coal seam A and B in the study area, b. Type of REY distribution of coal seam A and B in the study area. REY classified into Light Rare Earth Element (LREE), Medium Rare Earth Element (MREE), and Heavy Rare Earth Element (HREE), $\Sigma$ value is in ppm and c. LaN/LuN, LaN/SmN, and GdN/LuN ratios of coal seam A and B in the study area. These ratios define the enrichment type of REE in the coal including L-type, M-type and H-type. "N" signifies that the REE in the coal is normalized to Upper Continental Crust (UCC).
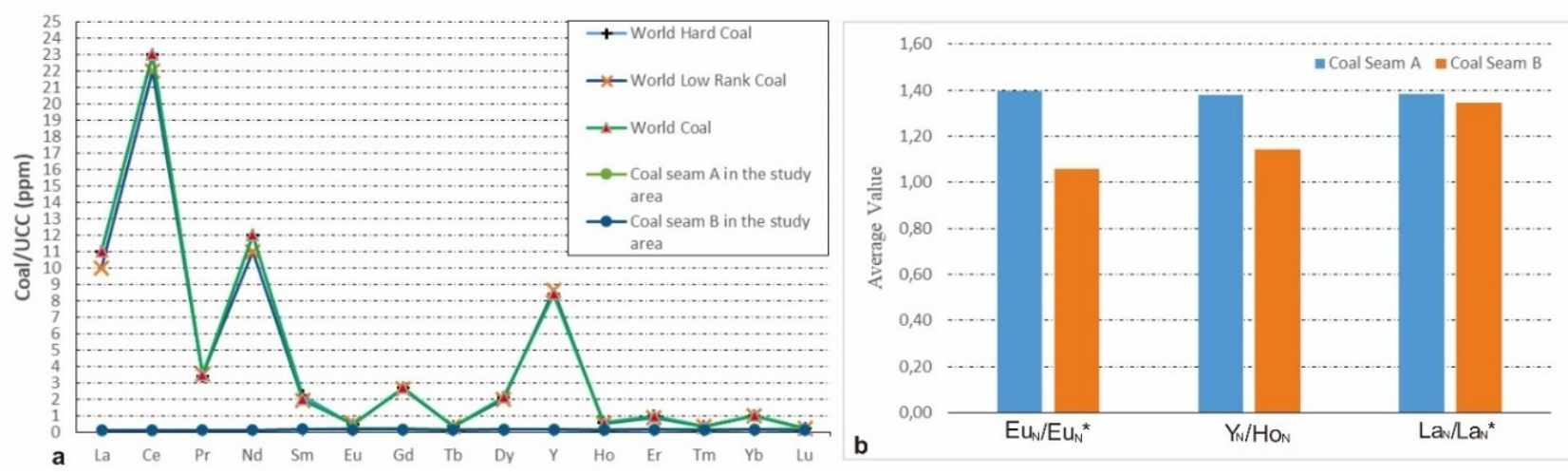

Fig. 4. a. REY element of coal in the study area compared to World Hard Coal, World Low Rank coal and World coal. b. The average value of $\mathrm{EuN} / \mathrm{EuN}^{*}, \mathrm{YN} / \mathrm{HoN}$ and $\mathrm{La} / \mathrm{LaN}^{*}$ ratio of coal in the studied area.

On the other hand, coal samples of 6PLY2, 6PLY4, 6PLY7 and 6PLY9 from coal seam B are typically characterised with M-type enrichment with LaN/LuN value varies from 0.85 to $0.98, \mathrm{LaN} / \mathrm{SmN}$ varies from 0.52 to 0.92 , and $\mathrm{GdN} / \mathrm{LuN}$ varies from 1.05 to 1.98 . While 6PLY1 and 6PLY5 coal samples are characterized with H-type enrichment with LaN/LuN value of 1.28 and $1.07, \mathrm{LaN} / \mathrm{SmN}$ value of 0.82 and 0.55 , and $\mathrm{GdN} / \mathrm{LuN}$ value of 1.60 and 1.84 (Figure $3 \mathrm{c}$ ).

REY distribution of coal has been normalized to UCC and compared to average value REY of World Hard Coal, World Low Rank Coal, and World Coal (see [1]). In general, coal seam $\mathrm{A}$ and $\mathrm{B}$ have REY distribution less than $0.5 \mathrm{ppm}$ (see Figure 4). The enrichment occurrence of trace element and REY in the coal can be divided into terrigenous, tuffaceous, hydrothermal, and infiltration [2]. The enrichment of REY deposits of coal in the study area is generally insignificant. The Tanjung Formation deposited overlaying of Late Cretaceous Kasale Vulcanic as a basement that mostly comprised of pyroxene basalt. The
REY elements deposits in the study area are interpreted as derived from terrigenous material from mafic basalt rocks. This is indicated by the average value ratio of the $\mathrm{LaN} / \mathrm{LaN}^{*}$ and $\mathrm{YN} / \mathrm{HoN}$ which are around 1.38 and 1.40 of coal seam $\mathrm{A}$, and also the average value of $\mathrm{LaN} / \mathrm{LaN}^{*}$ and $\mathrm{YN} / \mathrm{HoN}$ of coal seam $\mathrm{B}$ are around 1.35 and 1.14 .

As comparison, High-Ti and Low-Ti mafic basalt rocks from Kangdian Upland in China have a LaN/LaN* value ratio of 1.11 and 1.52 , and also $\mathrm{YN} / \mathrm{HoN}$ ratio value of 1.12 (Dai et al. 2016). Meanwhile, felsic and intermediate rocks have a $\mathrm{LaN} / \mathrm{LaN}^{*}$ values ratio varies from 0.75 to 0.85 or an average value of 0.85 , and also a anomalies value of $\mathrm{YN} / \mathrm{HoN}$ ratio around 0.95 [1].

A study of REY enrichment in coal in Indonesia has been done in Banko coalfield, Tanjung Enim, South Sumatra [6]. One of the samples, from Banko Coalfiled has a total of REY elements of around $118.4 \mathrm{ppm}$, and this concentration is higher than World Hard Coal, World Low Rank Coal, World Coal, and US Coal. Mode occurrence of REY element of coal in Banko is associated with the tuffaceous enrichment type. The 
enrichment origin of REY concentration was derived from leaching of silicic and alkali volcanic ash falls that also called tonsteins layers.

The felsic rock or felsic tonsteins generally has a negative value of $\mathrm{Eu}$ or EuN/EuN* and YN/HoN anomalies, while the mafic basalt has a positive anomalies value of $\mathrm{Eu}$ or $\mathrm{EuN} / \mathrm{EuN}^{*}$ and $\mathrm{YN} / \mathrm{HoN}$ [1]. The injection of volcanogenic hydrothermal solution process caused the positive $\mathrm{Eu} / \mathrm{EuN}^{*}$ ratio anomalies. $\mathrm{Ca}$ rich-mineral e.g. plagioclase feldspar also attributed to the enrichment of $\mathrm{Eu}$ elements which caused the replacement of $\mathrm{Ca} 2+$ with Eu2+. Even the coking coal in the Sekako area has a very low concentration of REY elements, it can be interpreted that REY concentration of coal in the study area related with the occurrence of volcanic mafic basalt rock.

\section{Conclusions}

a. Coking coal seam A and B of Tanjung Formation in the studied area generally have very low concentration of REY elements deposits.

b. REY elements deposits of coking coal seam A and $B$ in the study area are typically characterized with $M$ and H-type enrichment.

c. The REY elements deposits in coking coal seam A and $\mathrm{B}$ in the study area is interpreted related with the occurrence of mafic basalt rocks.

Authors thank PT. Suprabari Mapanindo Mineral (PT. SMM) for permission to take coal samples. This work was funded by the Ministry of Education and Culture under PDUPT UGM.

\section{References}

1. S. Dai, I.T. Graham, C.R. Ward, IJCG 159:82-95 (2016)

2. V.V. Seredin, S. Dai, IJCG, 94:67-93(2012)

3. J.M. Klinger, Extr Ind Soc, 5:1-7(2018)

4. A. Atmawinata, F. Yahya, S. Widhianto, Roosmariharso, D. Irianto, A. Adriano, Y. Susilo, W. Radjid, Massaruddin, D. Noviansyah, A.I. Sutjiatmo, V. Shinta, S. Wuri, B.P. Sutjiatmo, Ardhana, Telaah penguatan struktur industri pemetaan potensi logam tanah jarang di Indonesia, [Study of strengthening industrial structure mapping of rare earth metal potential in Indonesia]. Kementerian Perindustrian Republik Indonesia, 136 p. (2014). [in Bahasa Indonesia]

5. S. Dai, R.B. IJCG, 186:155-164(2018)
6. F. Anggara, D.H. Amijaya, A. Harijoko, T.N. Tambaria, A.A. Sahri, Z.A.N. Asa, IJCG, 196:159 172(2018)

7. S. Dai, D. Ren, C.L. Chou, R.B. Finkelman, V.V. Seredin, Y. Zhou, IJCG, 94:3-21(2012)

8. Ministry of Energy and Mineral Resources of Republic of Indonesia, HandBook of Energy and Economic Statistics of Indonesia (2018)

9. M.C. Friederich, T.M. Moore, R.M. Flores, IJCG, 166:2-35(2016)

10. M.C. Friederich, T. van Leeuwen, IJCG, 178:5673(2017)

11. C. Nas, and Hindartan, The Quality of Central Kalimantan Coking Coals. Kalimantan Coal and Mineral Resources, In Proceeding MGEI-IAGI, Balikpapan, pp. 1-11 (2010)

12. A.H. Satyana, M.P. Eka, M. Imron, Berita Sedimentologi, 3,17: 1-15 (2001)

13. A.H. Satyana, P.D. Silitonga, Tectonic reversal in East Barito Basin, South Kalimantan: consideration of the types of inversion structures and petroleum system significance, In: Proceedings of the IPA 23rd Annual Convention, pp. 57-74 (1994)

14. Soetrisno, S. Supriatna, E. Rustandi, P. Sanyoto, K. Hasan, Geological Map of The Buntok Quadrangle, Kalimantan, Geological Research and Development Centre (1994)

15. S. Supriatna, A. Sudrajat, H.Z. Abidin, Geological Map of The Muara Teweh Quadrangle, Kalimantan. Geological Research and Development Centre (1995)

16. D. Amarullah, Suatu Pemikiran Untuk Memanfaatkan Potensi Batubara Formasi Tanjung Di Daerah Lemo Kalimantan Tengah Sebagai Kokas. Kelompok Program Penelitian Energi Fosil, Pusat Sumber Daya Geologi, Bandung, 4, pp. 1-11. (2009) [in Bahasa Indonesia].

17. L. Thomas, Coal Geology, Second Edition, John Wiley \& Sons Ltd., West Sussex, 444 p. (2013)

18. M.N. Lamberson, R.M. Bustin, W. Kalkreuth, IJCG, 18:87-124(1991)

19. S.M. McLennan, Geosystems, 2:1021(2001)

20. B. Wiranata, H. Amijaya, F. Anggara, D.N.S.P. Tanggara, GEOSAPTA, 5,2: 151-157 (2019). [in Bahasa Indonesia].

21. Badan Nasional Penanggulangan Bencana, Peta Pulau Kalimantan, geospasial.bnpb.go.id (2009), [Accessed on May 2018]. 